\title{
Factors That Affect Tax Compliance among Small and Medium Enterprises (SMEs) in North Central Nigeria
}

\author{
Ojochogwu Winnie Atawodi ${ }^{1} \&$ Stephen Aanu Ojeka $^{1}$ \\ ${ }^{1}$ Department of Accounting, Covenant University, Ota, Ogun State, Nigeria \\ Correspondence: Ojochogwu Winnie Atawodi, Ahmadu Bello University, No. 74 Area F, Dodo Mustapha Ring, \\ Zaria, Nigeria. Tel: 234-813-901-8298. E-mail: chogwuwin@yahoo.com
}

Received: February 27, 2012 Accepted: April 13, 2012 Online Published: June 16, 2012

doi:10.5539/ijbm.v7n12p87 URL: http://dx.doi.org/ijbm.v7n12p87

\begin{abstract}
Tax is an important stream of revenue for government's development projects. However, tax compliance among SMEs is poor. Therefore, this study was conducted using SMEs in Zaria, North-Central Nigeria to evaluate and rank the factors that encourage non-compliance with tax obligation by SMEs. It was found that high tax rates and complex filing procedures are the most crucial factors causing non-compliance of SMEs. Other factors like multiple taxation and lack of proper enlightenment affect tax compliance among the SMEs surveyed only to a lesser extent. Therefore, it is recommended that SMEs should be levied lower percentage of taxes to allow enough funds for business development and better chances of survival in a competitive market. The government should also consider increasing tax incentives such as exemptions and tax holidays as these will not only encourage voluntary compliance but also attract investors who are potential viable tax payers in the future.
\end{abstract}

Keywords: taxation, developing economy, tax compliance, tax compliance costs, informal economy, SMEs

\section{Introduction}

Most large companies have their roots in small and medium enterprises suggesting that the future large corporations are the SMEs of today that that must be nurtured to ensure their growth. Thus, SMEs are generally perceived to be the seedbed for indigenous entrepreneurship and generate all the many small investments, which would otherwise not have taken place (Aryeetey \& Ahene, 2004). Therefore, developing economies like Nigeria needs to further the development of its private sector by creating an environment favorable to the growth of SMEs, strengthening the factors that lead to business success, and addressing the problems threatening the existence and advancement of small and medium enterprises (Chu, Kara \& Benzing, 2008), so they can adequately play the role expected of them in economic transformation. Such role includes mobilization of domestic savings for investment, appreciable contribution to gross domestic product, increased harnessing of local raw materials, employment generation, and significant contribution of poverty reduction efforts through sustainable livelihoods and enhancement in personnel income, technological development and export diversification (Smatrakalev, 2006). Furthermore, they have the advantage of reaching the farthest corners of the country unlike the larger establishments. For this reason, an ideal tax policy needs to be adopted in order to ensure voluntary compliance, economic growth and proper utilization of resources rather than suffocating the entrepreneur initiative they are out to cater for.

It is a well known fact that the revenue generated from the taxation of individuals and businesses is an important stream of income for government. In an economy like ours that is struggling to remain afloat, it is even more important. Tax revenue is the source of funds used for development projects such as provision of infrastructure like good roads, stable power supply, stable water supply etc. All of which combine to create an enabling environment for businesses - and in turn the economy at large- to grow.

Small and Medium Enterprises being profit generating establishments are also expected to pay their dues. The important question however is "how much tax should they be levied". Small and medium enterprises are volatile establishments that need special treatment. Putting their nature into consideration, every little resource at their disposal can make a world of difference. For this reason, a number of Nigerian SMEs choose to remain in the informal sector because they feel the cost of compliance is too high. And a considerable number of those who pay only do so because they are coerced by the authorities.

Since the individual SME pays a very small amount of tax compared what the larger establishment would pay, 
tax authorities tend give the larger corporations more attention. This means a good number of SMEs get away with not paying their taxes hence revenue that would otherwise have been invested in development projects that will end up being of benefit even to the SMEs is lost. This therefore is a situation that needs to be corrected.

The above brings to light reasons why the issue of taxation of SMEs is really important. First, tax provides revenue for the government to create an environment that will ease the running of all businesses SMEs inclusive. At the same time if an SME is faced with high compliance costs, it has a tendency to avoid paying taxes hence; the revenue that would have been used to create this environment is diminished thereby reducing the SME's chances of survival.

This research therefore is aimed at evaluating the factors that encourage non-compliance with tax obligation by SMEs and consequently determine if high tax rates tops the list. In doing this, a study was conducted using SMEs in Zaria, North-Central Nigeria.

\section{Literature Review}

\subsection{Definition of SMEs}

The Monetary Policy Circular No. 22 of 1988 of the Central Bank of Nigeria defined small-scale enterprises as enterprises whose annual turnover was not more than N500, 000. In the 1990 budget, the Federal Government of Nigeria defined small-scale enterprises for purposes of commercial bank loans as those with an annual turnover not exceeding N500, 000, and for Merchant Bank Loans, those enterprises with capital investments not exceeding 2 million naira (excluding cost of land) or a maximum of $\mathrm{N} 5$ million. The National Economic Reconstruction Fund (NERFUND) put the ceiling for small-scale industries at N10 million. Section 37b(2) of the Companies and Allied Matters Decree of 1990 defines a small company as one with an annual turnover of not more than N 2 million and net asset value of not more than 1 million naira (Ekpenyong \& Nyong, 1992). The Small and Medium Enterprise Equity Investment Scheme (SMEEIS) sees the SME as "any enterprise with a maximum asset base of N500 million (excluding land and working capital), and with no lower or upper limit of staff'. However, for tax purposes, Section 40(6) of the Companies Income Tax Act Cap C21 LFN 2004 alludes to companies with a turnover of $\mathrm{N} 1$ million and below operating in the manufacturing, agricultural production, solid mineral mining, and export trade sectors as SMEs; While subsection 8 states that as from 1988 all companies engaged in trade or business with a turnover of N500, 000.00 and below qualify as small and medium enterprises. (Iwuji, n.d)

\subsection{Characteristics of Small and Medium Enterprises}

The concept of SMEs is relative and dynamic (Olorunshola, 2003). SMEs are characterized by uncertainty, innovation and evolution. A firm understanding of SMEs would require a good knowledge of its features.

As noted by Aderemi (2003), SMEs in Nigeria are usually small, owner or family managed business offering basic goods and services, which tend to lack organizational and management structures with the urban ones tending to be more structural than their rural counterparts. This is one of the most generic features of SMEs in Nigeria.

Udechukwu (2003) goes on to state that they are mostly sole proprietorships or partnerships although on the surface, they may be registered as Limited Liability Companies as such they are usually not separate legal entities. Olorunshola (2003) explains that this ownership style has led small and medium enterprises to have a simple management structure. Factors also contributing to the reasons small and medium enterprises have a simple management structure are few number of employees and the owners' low level of education. Since there is no legal personality between the small and medium enterprise and its owners, it means the lifespan of the enterprise is dependent on the lifespan of its owners i.e. there is no perpetual continuity.

Furthermore, according to Hanefah, Ariff, \& Kasipillai (2002), the production processes of SMEs are usually labour intensive and they usually serve as suppliers for the larger manufacturing firms with their operations being highly dependent on raw materials sourced locally. They also require a lower startup capital than the larger companies (Akinsulire, 2010). The decisions of the managers have a higher tendency to be subjective given that they are managed and controlled by the same individual. The employee-employer relationship found in most SMEs is predominantly informal.

Another key feature of the SME sector in any country is that it is heterogeneous varying in size from small retail outlets to highly paid professionals, and substantial manufacturing enterprises. SMEs are also likely to vary in organizational form from sole proprietorships (with or without employees), small corporations (public or private), professionals and partnerships. This feature usually results in different obligations for record keeping for the enterprise. 
In addition, the contributions SMEs usually make to tax revenue are lower than its contributions to output and employment (International Tax Dialogue, 2007). That fact notwithstanding, SMEs have not become competitive enough to increase their share of output even though they form three-fifths of the number of manufacturing firms where larger manufacturing companies rely on SMEs for their supplies (Hanukah et. al, 2002).

SMEs are thought to be engine room of innovation this is because entrepreneurial activities such as innovation, risk bearing, employment creation, finding new opportunities and the commercialization of their inventions have been contributed to the prosperity in all regions of the world therefore, any country wishing to remain innovative will support SME growth because they also enhance competition and entrepreneurship and hence have external benefits on economy-wide efficiency, and aggregate productivity growth. Furthermore, SME proponents frequently claim that SMEs are more productive than large firms but financial market and other institutional failures impede SME development. Thus, pending financial and institutional improvements, direct government financial support to SMEs can boost economic growth and development (Avolio, n. d, Beck, Demirguc-Kunt \& Levine, 2005; Chu, Kara \& Benzing, 2008).

Honlglang \& Jiaozben (n. d) agree with the fact that SMEs foster economic growth through innovation by stating that during the economic globalization period and under fierce competition conditions, the research and development activities of small and medium-sized enterprises play an irreplaceable role in promoting technology innovation and national economic development because of their adaptive ability in market, flexible operation mechanism as well as innovation spirit. As a result of this, they can adapt to new situations more easily than large corporations. Innovation is also critical for getting new ideas into the economy (Hendy, 2003). Small and Medium Enterprises serve as links between the large business enterprise and the consumers as such, large enterprises can hardly survive without them. Therefore, the importance of small business enterprises cannot be over emphasized. Small business enterprises make a larger contribution pro rata in the economy and with efficient control and management techniques of SMEs the benefit it gives can be much greater.

Small and medium scale enterprises according to Akinsulire (2010) accelerate rural development while decreasing urban immigration and the problems of congestion in large cities because they have lesser competition by serving dispersed local markets, are closer to their resources and are cheaper to establish in the urban areas entrepreneurs are attracted to invest thus discouraging rural-urban migration and making for an even development. SMEs also contribute to domestic capital formation, play a value-adding role, mobilize private savings and harness them for productive purposes.

Kilby (1969) as cited in Ekpenyong \& Nyong (1992) sees SMEs as a quasi sponge for urban employment and a provider of inexpensive consumer goods with little or no import content, serving an important pressure-releasing and welfare-augmenting function. SMEs also contribute to long-run industrial growth by producing an increasing number of firms that grow up and out of the small-scale sector. The emergence of wholly modern small/medium-scale Nigerian industries is likely to be a prerequisite for any enduring industrialization.

Other contributions made by SMEs to the economy according to Hendy (2003) include being able to remain profitable even in turbulent conditions because they are accustomed to operating in highly fragmented and heterogenous markets, Also, they often serve a special role in creating social capital (that is, they are often 'entrenched' in local communities) another advantage is that because they are fast and flexible, and close to their customers, they can be a competitive spur to large firms. Output growth; they perform important sub-contract functions; they can perform an important import substitution role, while others are exporters.

\subsection{Taxation of SMEs}

Fiscal policy is one of the main components of macroeconomic policy and its tasks have been considered in a double context: first, the core of fiscal policy, and second, the consistency with the monetary policy (Holban, 2007). In general terms, the choice of tax policy to employ depends on the use of one or both two groups of instruments; the first one being the use of special tax preferences and the other incentives to support start-up and growth of small companies. The incentives include the lowering of corporate income tax rates, special tax exemptions and relieves for small businesses.

The fundamental purpose of taxation is to raise revenue effectively, through measures that suit each country's circumstances and administrative capacity. In fulfilling the revenue function, a well designed tax system should be efficient in minimizing the distortionary impact on resource allocation, and equitable in its impact on different groups in society (Bolnick, 2004). It is important that the country's situation is properly analyzed before employing any tax policy in order have a properly working tax system because according to Slemrod, J. (n. d) Many of the difficulties with the tax authorities are the consequence of poorly conceived tax policies and a lack of certainty regarding future policy changes. The objective of a tax policy should be to achieve collection cost 
savings while minimizing the revenue loss, disruption to the economy, and the inequity and capriciousness of the tax burden.

For an economy such as Nigeria that is still in the throes of a recession, the tax regime must be versatile enough to encourage savings, stimulate investment and reward social responsibility and research funding. To widen the tax net, policy makers must never forget the urgency to provide infrastructure; create jobs and reduce unemployment; expand the productive sectors of the economy; stimulate exports, and substantially raise public revenues from non-oil sources (Punch, 2010). Hence, tax policies should aim at bringing all taxable adults into the tax net with a graduated rate that should ensure that the well-off pay their own share while the low income earners are given savings-enhancing incentives.

An effective and efficient tax administration system is integral to any country's well being, it is as a result of this that Baurer (2005) believes that the tax administration must provide an even playing field for business by ensuring that all taxpayers meet their tax filing and paying requirements The tax administration must balance its educational and assistance role with its enforcement role.

The rationale behind the whole system of tax is consistent with two of the three major theories of tax namely; the Ability-to-Pay Principle and the Equal Distribution Principle. These two principles stress equality and fairness. While the Ability-to-Pay talks pushes that individuals should be levied taxes based on their ability to pay, the Equal distribution Principle suggests that income, wealth, and transaction should be taxed at a fixed percentage; that is, people who earn more and buy more should pay more taxes, but will not pay a higher rate of taxes (Gabay, Remotin, \& Uy, n.d)

\subsection{Tax Compliance and SMEs}

According to Marti (2010) tax compliance is a complex term to define. Simply put, tax compliance refers to fulfilling all tax obligations as specified by the law freely and completely.

It has been found that regulatory burdens fall disproportionately on small and medium enterprises internationally (Pope \& Abdul-Jabbar, 2008). Their size and nature makes the issue of tax compliance one of particular importance especially since most SMEs have access to limited resources and inadequate expertise to comply with diverse and complicated regulation. He also believes that high compliance costs can result in tax avoidance, tax fraud, and inhibit investment by way of diminishing competitiveness of the country in terms of taxation attractiveness.

Tax non-compliance may be in one of many forms; it could either be failure to submit a tax return within the stipulated period or non submission, understatement of income, overstatement of deductions, failure to pay assessed taxes by due date. (Kasipillai \& Abdul Jabbar, 2006) and in some cases non-compliance may mean an outright failure to pay levied taxes.

Studies have shown that the problem of tax evasion is a widespread one (Kasipillai \& Abdul Jabbar, 2006). Furthermore, Fagbemi, Uadile \& Noah (2010) found that it is prevalent in developing countries and it hinders development thereby leading to economic stagnation and other socio-economic problems. Chipeta (2002) identified tax rates as one of the causes of tax evasion. He pointed out that a higher tax rate increases taxpayers' burden and reduces their disposable income therefore, the probability of evading tax is higher.

\subsection{Tax Policy and Level of Voluntary Compliance among SMEs}

Small taxpayers under the regular system of taxation are discriminated against, since the compliance requirements, cost of compliance and tax rate are the same for both small and large enterprises. Reducing the compliance costs and tax rate increases the small enterprises profit margin. It also increases the Government's tax revenue, since the simplified provisions for small and medium enterprises reduce the size of the informal economy and the number of non-complying registered taxpayers (Vasak, 2008). Furthermore, SMEs usually have to operate in an overbearing regulatory environment with the plethora of regulatory agencies, multiple taxes, cumbersome importation procedure and high port charges that constantly exert serious burden on their operations. An overly complex regulatory system and tax regime or one opaque in its administration and enforcement makes tax compliance unduly burdensome and often have a distortionary effect on the development of SMEs as they are tempted to morph into forms that offer a lower tax burden or no tax burden at all (Masato, 2009), and this results in a tax system that imposes high expenses on the society. A poorly executed tax system also leads to low efficiency, high collection charges, waste of time for taxpayers and the staff, and the low amounts of received taxes and the deviation of optimum allocation of resources (Farzbod, 2000). Existing empirical evidence clearly indicates that small and medium sized businesses are affected disproportionately by these costs: when scaled by sales or assets, the compliance costs of SMEs are higher than for large businesses 
(Weichenrieder, 2007).

\subsection{Tax Policy that will Encourage Voluntary Compliance by SMEs}

SMEs constitute untapped revenue potential and an uneven playing field in many countries (International Tax Dialogue, 2007) as such they need to be captured by the tax net. However, though legislations are necessary regulator for protection of the business environment and security of the economic agents, for establishment of the necessary social security regulations, they may also hamper compliance and the growth of business through additional expenditures and administrative obstacles. Thus Shahroodi, (2010) stated that for a tax system to be efficient, the tax policy needs to be designed such that the tax rates are appropriate and rational, the exemptions are lower in amount, the tax collection organization are more efficient, the tax burden of the indigent people should be lighter and the fight against corruption and tax evasion should be much more intense.

Tax policies can be designed in such a way that they do not only directly affect SMEs but also indirectly push for voluntary compliance and their growth. Yaobin (2007), emphasized declared that special tax regimes for SMEs may be appropriate policy instruments for minimizing the cost of collection. Because awareness of the dangers of inadequate taxation of SMEs has grown because of the potential of uneven tax enforcement to cause distortions of competition, voluntary compliance by larger enterprises and by wage earners, (International Tax Dialogue, 2007), government intervention should help maintain balance while ensuring that countries exploit the social benefits from greater competition and entrepreneurship. Pro-business (and Pro-SME) Tax regimes and enforcement should be simple, consistent and predictable should to lower compliance and administrative costs, and hence reduce uncertainty faced by taxpayers as well as improve the levels of voluntary compliance (Kasipillai, 2005).

\subsection{Theories of Tax Compliance}

Various opinions exist about the best ways to improve tax compliance. Given the chance, a lot of businesses will not pay taxes unless there is a motivation to do so. Some believe that the best way is to increase incentives (Feld \& Frey, 2007) others believe the best way is to increase penalties. Tax compliance theories can be broadly classified into two. They are; economics based theories and psychology based theories.

\subsubsection{Economic Based Theories}

They are also known as deterrence theory and they place emphasis on incentives. The theory suggests that taxpayers are amoral utility maximizers- they are influenced by economic motives such as profit maximization and probability of detection. As such they analyze alternative compliance paths for instance whether or not to evade tax, the likelihood of being detected and the resulting repercussions and then select the alternative that maximises their expected after tax returns after adjusting for risk. This process is referred to as "playing the audit lottery" by Trivedi and Shehata (2005). Therefore according to the theory, in order to improve compliance, audits and penalties for non-compliance should be increased.

\subsubsection{Psychology Theories}

Psychology theories on the other hand posit that taxpayers are influenced to comply with their tax obligations by psychological factors. They focus on the taxpayers' morals and ethics. The theories suggest that a taxpayer may comply even when the probability of detection is low. As opposed to the economic theories that emphasize increased audits and penalties as solutions to compliance issues, psychology theories lay emphasis on changing individual attitudes towards tax systems.

\section{Statement of Research Hypothesis}

$\mathrm{H}_{0}$ : There are other factors more important than high tax rates that influence SMEs' failure to pay tax in Nigeria.

$\mathrm{H}_{1}$ : High tax rate is the most crucial factor influencing SMEs' failure to pay tax in Nigeria.

\section{Research Methods}

\subsection{Data Collection}

Data for this research was collected from primary sources. Putting the research objectives into consideration, the survey method was employed using questionnaires, personal interviews with respondents. The questionnaire consisted of properly constructed open and close ended questions in order make it easier to obtain precise answers from the respondents. Expert opinion was sought for in order to validate the content and the structure of the questionnaire during the pilot study. The sample was obtained using a combination of non-probability sampling and probability sampling methods. In an attempt to obtain a fair representation of the population, the selection of small and medium enterprises was done using both judgmental sampling and random sampling. 
Since there is a limited number of partnership businesses and limited liability companies in Zaria, as many of these businesses as possible were deliberately selected to be part of the sample and then the sole proprietorships were randomly selected to make up the number to 150 SMEs. Of the questionnaires retrieved, $69.2 \%$ were from sole proprietorships, $21.5 \%$ were from partnership businesses and the remaining $9.3 \%$ of the SMEs sampled were from limited liability companies. The SMEs were at different stages of development with some being older and hence more established than others $-37.4 \%$ of them were new businesses with an age range of $0-3$ years, $27.1 \%$ had an age range of $4-7$ years and $35.5 \%$ of the SMEs were more established businesses being 8 years old and over.

\subsection{Methodology}

The location of study for this research is Zaria, Kaduna State. Of the 150 questionnaires distributed, 107 were returned and 43 were not. A retrieval rate of $71.33 \%$ considered reliable enough to base a research on was obtained from the survey. The parametric one sample Z-test was used to test this hypothesis. The one-sample z-test is a test to determine if there is a significant difference between the mean of a sample and the hypothesized mean of the population. It is usually used when the sample size (n) is greater than $30(n>30)$ hence it is an appropriate test since sample size is $150(\mathrm{n}=150)$. This hypothesis was tested with Microsoft Office Excel 2007 using the one sample z-test computed from the figures obtained in the summary statistics table.

The z-measure is calculated using the following formula:

Where

$$
z=\frac{\bar{x}-\Delta}{\frac{\sigma}{\sqrt{n}}}
$$

$\mathrm{x}=$ sample mean

$\Delta=$ specified value to be tested i.e. the hypothesized mean,

$\sigma=$ the population standard deviation,

$\mathrm{n}=$ the size of the sample.

The function in excel used to obtain the $\mathrm{Z}$ (obtained) is as follows:

"=Mean-Hypothesized Mean/Standard Error"

Whereas, the ZTEST function was used obtain the p-value.

4.3 Analysis, Findings and Discussion of Results

4.3.1 Analysis of Taxes Paid by SMEs

Table 1. Analysis of percentage of profits paid as tax

\begin{tabular}{lccccc}
\hline & & Frequency & Percent & Valid Percent & Cumulative Percent \\
\hline Valid & $0 \%$ & 33 & 30.8 & 36.3 & 36.3 \\
& $1-10 \%$ & 30 & 28.0 & 33.0 & 69.2 \\
& $11-20 \%$ & 10 & 9.3 & 11.0 & 80.2 \\
& $21-30 \%$ & 7 & 6.5 & 7.7 & 87.9 \\
& $31-40 \%$ & 3 & 2.8 & 3.3 & 91.2 \\
& $41-50 \%$ & 6 & 5.6 & 6.6 & 97.8 \\
& $51-60 \%$ & 1 & .9 & 1.1 & 98.9 \\
& $61-70 \%$ & 1 & .9 & 1.1 & 100.0 \\
Missing & Total & 91 & 85.0 & 100.0 & \\
Total & & 16 & 15.0 & & \\
\hline
\end{tabular}

Source: Field Survey 2011

Table 1 shows the distribution of respondents according to how much tax they pay. It shows that 33 SMEs 
(30.8\%) pay no taxes at all, 30(28.0\%) pay tax of between $1-10 \%$ of their profit, $10(9.3 \%)$ pay between $11-20 \%$ of their profit as tax, 7 SMEs pay a tax which falls within a range of $21-30 \%$ of their profit, 3 SMEs $(2.8 \%)$ pay between $31-40 \%$ of their profit as tax, $6(5.6 \%)$ pay a tax of between $41-50 \%$ of profit as tax, finally, $1 \mathrm{SME}$ $(0.9 \%)$ each pay between $51-60 \%$ and $61-70 \%$ of their profit as tax. However, 16 SMEs did not disclose the amount of tax they pay and left the question blank. From the table, it can be observed that a significant proportion of SMEs in Zaria, Kaduna State do not pay taxes and are such in the informal economy.

4.3.2 Analysis of the Causes of Non-Compliance

Table 2. Analysis of causes of sme non-compliance

\begin{tabular}{|c|c|c|c|c|c|}
\hline & & Frequency & Percent & $\begin{array}{l}\text { Valid } \\
\text { Percent }\end{array}$ & $\begin{array}{l}\text { Cumulativ } \\
\text { e Percent }\end{array}$ \\
\hline \multirow[t]{4}{*}{ Valid } & Tax rates are too high & 58 & 48.7 & 48.7 & 48.7 \\
\hline & $\begin{array}{l}\text { The procedures for tax filing are too } \\
\text { complicated }\end{array}$ & 28 & 23.5 & 23.5 & 72.3 \\
\hline & $\begin{array}{l}\text { Never been requested to pay taxes by the } \\
\text { government }\end{array}$ & 33 & 27.7 & 27.7 & 100.0 \\
\hline & Total & 119 & 100.0 & 100.0 & \\
\hline
\end{tabular}

Source: Field Survey 2011

This question has three options namely: Tax rates are too high; The procedures for tax filing are too complicated and SMEs have never been requested to pay taxes by the government. Option "a" was selected $58(48.7 \%)$ times, option "b" was selected 28(23.5\%) times and option "c" occurred 33(27.7\%) times. A total of $72.3 \%$ of all the respondents attributed SMEs non-compliance to high tax rates and complicated filing procedures. From the above, it could also be seen that the major cause of tax non-compliance is high tax rates.

\subsubsection{Analysis of Small Business Owners Opinion on Tax-Related Government Assistance}

Table 3. Analysis of tax-related government assistance

\begin{tabular}{|c|c|c|c|c|c|}
\hline & & Frequency & Percent & $\begin{array}{c}\text { Valid } \\
\text { Percent }\end{array}$ & $\begin{array}{c}\text { Cumulative } \\
\text { Percent }\end{array}$ \\
\hline \multirow[t]{5}{*}{ Valid } & Reducing tax rates & 70 & 58.3 & 58.3 & 58.3 \\
\hline & Granting tax holidays & 8 & 6.7 & 6.7 & 65.0 \\
\hline & Granting tax exemptions & 11 & 9.2 & 9.2 & 74.2 \\
\hline & $\begin{array}{l}\text { Strengthening the services of tax } \\
\text { authorities towards SMEs }\end{array}$ & 31 & 25.8 & 25.8 & 100.0 \\
\hline & Total & 120 & 100.0 & 100.0 & \\
\hline
\end{tabular}

Source: Field Survey 2011

Small Business owners were asked how they thought the government could assist them in making their business grow and the four answer options were; by reducing tax rates, granting tax holidays, by granting tax exemptions, by strengthening the services of tax authorities towards SMEs. The highest appearing option is option "a" which occurs 70 times (58.3\%), followed by option d which has been selected 31 times $(25.8 \%)$ and then option "c" occurring 11 times $(9.2 \%)$ and finally option "b" which occurs 8 times $(6.7 \%)$. It can be seen that the business owners are of the opinion that getting better services from the government tax agencies are more important than getting tax holidays. However, reduced tax rates are considered most important. From this data, it can be said that most SMEs do not mind paying taxes provided the tax rates are lower and they can file their taxes in a simple manner. 


\subsection{Test of Hypothesis}

Table 4. Test of hypothesis: one-sample z-test

\begin{tabular}{|c|c|}
\hline \multicolumn{2}{|c|}{ Summary Statistics } \\
\hline Mean & 1.789915966 \\
\hline Standard Error & 0.078144292 \\
\hline Median & 2 \\
\hline Mode & 1 \\
\hline Standard Deviation & 0.852453583 \\
\hline Sample Variance & 0.726677112 \\
\hline Kurtosis & -1.500781986 \\
\hline Skewness & 0.419468258 \\
\hline Range & 2 \\
\hline Minimum & 1 \\
\hline Maximum & 3 \\
\hline Sum & 213 \\
\hline Count & 119 \\
\hline Largest(1) & 3 \\
\hline Smallest(1) & 1 \\
\hline Confidence Level (95.0\%) & 0.154746971 \\
\hline \multicolumn{2}{|l|}{ Z-Test } \\
\hline z-value & 10.10842824 \\
\hline p-value & 0 \\
\hline
\end{tabular}

The $\mathrm{Z}$ (obtained) for this test is 10.10842824 and at a $5 \%$ two-tailed level of significance, it is greater than the $\mathrm{Z}$ (critical) which is 1.96. In addition, the p-value obtained is 0 hence, and this implies that the sample mean is not different from the hypothesized mean. Hence, the null hypothesis $\left(\mathrm{H}_{0}\right)$ will be rejected and the alternative hypothesis $\left(\mathrm{H}_{1}\right)$ will be accepted. Therefore, high tax rates are the most crucial factors influencing SMEs' failure to pay tax in Nigeria.

The $\mathrm{Z}$ value obtained shows that the sample was taken from a population whose mean is 1 and 1 represents the option that high tax rates are the primary reason most SMEs do not pay tax. Since the p-value obtained is less than the level of significance, it can be said that the probability of rejecting the hypothesis that the population and sample means are the same. This can be supported by the works of Ačevska (2002), who from a study of Macedonian SMEs found out that the most serious institutional barriers for Macedonian SMEs are the high taxes. In agreement also is the work of Lavinia \& Alecxandrina (2006) carried in Romania which reports that taxation is the most significant difficulty faced by entrepreneurs.

\section{Conclusion and Recommendations}

Based on the findings above, it can be concluded that when it comes to taxation of SMEs, high tax rates are the primary problem of entrepreneurs. Despite the fact that they face other tax related issues, it is the problem of high tax rate that mostly promotes non-compliance and pushes most SMEs to remain in the informal sector. Hence, SMEs are deprived of the benefits that arise if the government had enough tax revenue to embark on some development projects provision of amenities such as electricity and good roads which are tools that create an enabling environment for SMEs to thrive.

\subsection{Recommendations}

i. Small and Medium Enterprises should be levied lower amounts of taxes so that they will have enough funds for other activities that will lead to business growth. Furthermore it will help SMEs get better equipped to survive in a competitive market.

ii. The government should consider increasing tax incentives and exemptions as this will not only attract investors who are potential tax payers, it will also encourage voluntary compliance. 


\section{References}

Ačevska, B. (2002). Entrepreneurship under difficult circumstances: factors hindering SME growth in the Republic of Macedonia. South-East Europe Review for Labour and Social Affairs, 1, 109-122.

Aderemi, A. (2003, June). Small and medium scale enterprises: The Nigerian situation. [Power Point Slides] Capital Partners Limited. Retrieved from www.capitalpartnersltd.com/Small\%20Medium\%20Scale.ppt

Akinsulire, O. (2010). Financial management. Lagos: Ceemol.

Aryeetey, E., \& Ahene, A. (2004). Changing regulatory environment for small-medium size enterprises and their performance in Ghana. CRC Working Paper No. 30594, Centre on Regulation and Competition (CRC). Retrieved from http://ageconsearch.umn.edu/bitstream/30594/1/cr050103.pdf

Avolio, C. (n. d.). Policies for business in the Mediterranean Countries Slovenia. Retrieved from http://unpan1.un.org/intradoc/groups/public/documents/caimed/unpan018702.pdf

Baurer, L. I. (2005) Tax administrations and small and medium enterprises (SMEs) in Developing Countries. Retrieved from http://www.ifc.org/ifcext/sme.nsf/AttachmentsByTitle/BEE+SME+Taxation/\$FILE/SME+Taxation+Toolkit .pdf

Beck, T., Demirguc-Kunt, A., \& Levine R. (2005). SMEs, growth, and poverty: cross country evidence. NBER Working Paper 11224, National Bureau of Economic Research. Retrieved from http://www.nber.org/papers/w11224.pdf

Bolnick, B. (2004). Effectiveness and Economic Impact of Tax Incentives in the SADC Region. Arlington, Virginia: Nathan Associates Inc.

Chu, H. M., Kara, O., \& Benzing, C. (2008). An empirical study of Nigerian entrepreneurs: success, motivations, problems, and stress. International Journal of Business Research, 8(2), 102-116.

Ekpenyong, D. B., \& Nyong M. O. (1992). Small and medium-scale enterprises in Nigeria: their characteristics, problems and sources of finance. (Research Paper 16). Retrieved from http://idl-bnc.idrc.ca/dspace/bitstream/10625/9982/1/95971.pdf

Fagbemi, O. T., Uadile, O. M., \& Noah, A. O. (2010). The ethics of tax evasion: perpetual evidence from Nigeria. European Journal of Social Sciences, 17(3), 360-371.

Farzbod, J. (2000). Investigation of the effective factors in the tax efficiency. Unpublished master's thesis, Governmental Management Training Center, Tehran.

Feld, L. P., \& Frey, B. S. (2007). Tax compliance as the result of a psychological tax contract: the role of incentives and responsive regulation. Law and Policy, 29(1), 102-120. http://dx.doi.org/10.1111/j.1467-9930.2007.00248.x

Gabay, B. K. G., Remotin, Jr. R. M., \& Uy, E. A. M. (2007). Economics: its concepts and principles. Retrieved from http://www.slideshare.net/gar_dev/concepts-of-taxation

Göndör, M. (2011). SME's Fiscal Compliance Costs as a Matter of Common Concern. In G. Thomas, C. Fleaurant, T. Panagopoulos, E. Chevaussus-Loza, \& J. Strouhal. (Eds.), Recent Researches in Economics and Management Transformation. Proceedings of the 6th IASME/WSEAS International Conference on Economy and Management Transformation held in Angers, France 17-19 November, 2011 (pp. 163-167). WSEAS press.

Hanefah, M., Ariff, M., \& Kasipillai, J. (2002). Compliance costs of Small and Medium Enterprises. Journal of Australian Taxation, 4(1), 73-97.

Hendy, P. (2003, August). Threats to Small and Medium sized Enterprises from Tax and other Regulations. Paper presented at the Australian Taxation Studies Program Small Business Tax Symposium, Developing Good Tax Policies for SMEs, Sydney.

Holban, O. I. (2007). The taxation of small and medium-sized enterprises-a hindering factor influencing the european economic growth. Doctoral dissertation, Alexandru Ioan Cuza University of Iasi and Academy of Economies Studies from Bucharest Romania.

Honglang, L., \& Jiaozben, H. (2010). Research on R\&D financing support for small and medium-sized enterprises. Orient Academic Forum. Retrieved from http://www.seiofbluemountain.com/upload/product/201009/2010cwjrhy04a1.pdf 
International Tax Dialogue. (2007). Taxation of Small and Medium Enterprises. Background paper for the International Tax Dialogue Conference, Bueons Aires.

Iwuji, G. I. (2009). Creating awareness on tax matters for small and medium units. [PowerPoint Slides]. Retrieved

from http://www.docstoc.com/docs/19747636/Creating-Small-and-Medium-Enterprises-Tax-Matters-Awareness.

Lavinia, R., \& Alecxandrina, D. (2006). Romanian small and medium sized enterprises- challenges upon accession into the European Union.

Marti, L. O. (2010). Taxpayers' attitudes and tax compliance behaviour in Kenya. African Journal of Business \& Management, 1,112-122.

Olorunshola, J. A. (2003). Problems and prospects of small and medium scale industries in Nigeria. Paper presented at the Central Bank of Nigeria seminar on small and medium industries equity investment scheme (SMIEIS). Retrieved from www.cenbank.org/out/Publications/guidelines/dfd/2004/smieis.pdf

Pope, J., \& Abdul-Jabbar, H. (2008). Tax Compliance Costs of Small and Medium Enterprises in Malaysia: Policy Implications.

Reviewing Nigeria's tax Policy (2010, January 28). Punch. Retrieved from http://www.punchng.com/Maincat.aspx?thecat=BUSINESS

Shahrodi, S. M. M. (2010). Investigation of the effective factors in the efficiency of tax system. Journal of Accounting and Taxation, 2(3), 42-45.

Slemrod, J. (n. d). Taxation of SMEs and sustainable economic development. Retrieved from http://www.itdweb.org/smeconference/documents/plenary/PI\%20Slemrod\%20ENG.pdf

Smatrakalev, G. (2006). Tax policy for small and medium enterprises. Paper deliverd at the $6^{\mathrm{TH}}$ Global conference on business and economics. U.S.A: Gut man conference center.

Udechukwu, F. N. (2003). Survey of small and medium scale industries and their potentials in Nigeria. Paper presented at the Central Bank of Nigeria seminar on small and medium industries equity investment scheme (SMIEIS). Retrieved from www.cenbank.org/out/Publications/guidelines/dfd/2004/smieis.pdf

Vasak, S. (2008). Small, medium, and large enterprises. USAID Business Climate Reform. Retrieved from http://pdf.usaid.gov/pdf_docs/PNADQ675.pdf

Weichenrieder, A. J. (2007). Survey on the taxation of small and medium-sized enterprises: draft report on responses to the questionnaire. Retrieved from http://www.oecd.org/dataoecd/52/25/39597756.pdf

Yaobin, S. (2007, October). Tax, small business, growth: effect of taxation on investment and cross-border trade. Paper presented at the ITD Conference on Taxation of SMEs. 